Published by LPMP Imperium

Journal homepage: https:/ / ejournal.imperiuminstitute.org/ index.php/JMSAB

\title{
Model hubungan informasi non keuangan dengan initial return dan return saham 7 hari
}

\author{
Basuki Toto Rahmanto* \\ Manajemen, Fakultas Bisnis Institut Teknologi dan Bisnis Kalbis
}

\section{Febriansyah}

Manajemen, Fakultas Bisnis Institut Teknologi dan Bisnis Kalbis
JMSAB

107

Paper type

Research paper

Keywords: Non-Financial Information, Stocks

Received: 24 Jun 2019

Revised: 12 Jul 2019

Accepted: 15 Jul 2019

Online: 14 Aug 2019

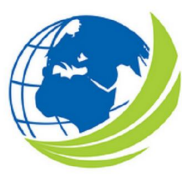
Jurnal Manajemen
Strategi dan Aplikasi
Bisnis, Vol 2, No. 2,
August 2019,
pp. 107 - 116
eISSN 2655-237X

*Email korespondensi: basuki.rahmanto@kalbis.ac.id

Pedoman Sitasi: Rahmanto, B.T \& Febriansyah (2019). Model hubungan informasi non keuangan dengan nitial return dan return saham 7 hari. Jurnal Manajemen Strategi dan Aplikasi Bisnis, 2(2), 107 - 116 


\section{PENDAHULUAN}

Pada umumnya setiap perusahaan ingin memperluas usahanya dengan mengadakan ekspansi dimana dalam melakukan ekspansi, perusahaan memerlukan modal yang cukup besar. Untuk pemenuhan modal tersebut seringkali dana yang diambil dari dalam perusahaan tidak cukup sehingga diperlukan usaha mencari sumber dana dari luar perusahaan yaitu di pasar modal dengan cara melakukan emisi saham. Menurut Alwi (2003:14) secara formal pasar modal didefinisikan sebagai pasar untuk berbagai instrumen keuangan (sekuritas) jangka panjang yang diperjualbelikan, baik dalam bentuk hutang ataupun modal sendiri yang diterbitkan pemerintah, public authorities, maupun perusahaan swasta. Pasar modal dalam arti sempit adalah suatu tempat yang terorganisasi dimana efek-efek diperdagangkan. Pasar modal dalam bentuk konkrit berupa bursa efek (stock exchange) yaitu suatu sistem yang terorganisasi yang mempertemukan penjual dan pembeli efek yang dilakukan baik secara langsung maupun wakil-wakilnya.

Pasar modal memainkan peran besar dalam perekonomian karena memiliki dua fungsi, yaitu fungsi ekonomi dan fungsi keuangan. Dikatakan memiliki fungsi ekonomi karena menyediakan fasilitas atau wahana yang mempertemukan dua kepentingan, yaitu pihak yang memerlukan dana (issuer) dan pihak yang memiliki kelebihan dana (investor). Melalui pasar modal maka pihak investor dapat menginvestasikan dana tersebut dengan harapan memperoleh imbalan (return) sedangkan pihak issuer dalam hal ini perusahaan dapat memanfaatkan dana tersebut untuk kepentingan investasi tanpa harus menunggu tersedianya dana dari operasi perusahaan. Pasar modal dikatakan memiliki fungsi keuangan, karena pasar modal membuka kemungkinan dan kesempatan bagi pemilik dana untuk memperoleh imbalan yang sesuai dengan karakteristik investasi yang dipilihnya.

Menurut Jogiyanto (2003:5) investasi dapat didefinisikan sebagai penundaan konsumsi sekarang untuk digunakan di dalam produksi yang effisien selama periode waktu yang tertentu. Penundaan konsumsi sekarang yang dimasukkan ke dalam aktiva atau proses produksi yang produktif yang hasilnya untuk konsumsi mendatang dapat dikatakan sebagai suatu investasi. Dengan adanya proses produksi yang produktif, investasi ke produksi ini dapat meningkatkan kepuasan (utility) individu. Investasi ke dalam produksi yang efisien dapat berbentuk aktiva nyata (seperti rumah, tanah, dan emas) atau berbentuk aktiva keuangan (surat-surat berharga) yang diperjual-belikan di antara investor (pemodal). Investor melakukan investasi untuk meningkatkan utility-nya dalam bentuk kesejahteraan keuangan.

Proses penawaran sebagian saham perusahaan kepada masyarakat untuk pertama kali atau penawaran umum perdana melalui bursa efek disebut Initial Public Offerings (IPO). Perusahaan yang melakukan penawaran umum perdana berarti perusahaan tersebut go public. Dengan go public, maka perusahaan dapat menghimpun dana dari masyarakat yang relatif besar. Dana tersebut dapat digunakan untuk keperluan pendanaan, membiayai kegiatan operasi perusahaan, ekspansi, serta memperbaiki struktur modal perusahaan.

Pada saat perusahaan melakukan IPO, harga saham yang dijual di pasar perdana ditentukan berdasarkan kesepakatan antara perusahaan emiten dan penjamin emisi (underwriter). Sedangkan harga saham di pasar sekunder (setelah IPO) ditentukan oleh mekanisme pasar, yaitu permintaan dan penawaran. Apabila penentuan harga saham pada saat IPO secara signifikan lebih rendah dibandingkan dengan harga yang terjadi di pasar sekunder di hari pertama, maka terjadi return awal yang tinggi. Kondisi tersebut tidak menguntungkan bagi perusahaan yang melakukan go public, karena dana yang diperoleh tidak maksimum.

Return awal atau initial return adalah tingkat pengembalian awal yang diperoleh pemegang saham karena perbedaan harga saham yang dibeli di pasar perdana (saat IPO) dengan harga jual saham yang bersangkutan di hari pertama di pasar sekunder. Perbedaan kepentingan dimana dari sisi pembeli, mereka menginginkan harga perdana yang rendah sehingga dapat memperoleh initial return sedangkan para pemilik perusahaan menginginkan agar dapat meminimalisir initial return, karena terjadinya initial return yang tinggi akan menyebabkan transfer kemakmuran dari pemilik kepada investor. Fenomena initial return dikarenakan adanya mispriced di pasar perdana sebagai akibat adanya ketidak seimbangan informasi antara pihak penjamin emisi dengan pihak perusahaan (emiten), antara perusahaan (emiten) dengan investor maupun adanya ketidak seimbangan informasi antar investor. 
Berdasarkan uraian di atas, fenomena initial return merupakan salah satu hal yang menarik untuk dibahas. Penelitian ini merupakan pengembangan dari beberapa penelitian terdahulu, perbedaan penelitian ini dengan penelitian terdahulu yaitu penelitian ini fokus pada perusahaan-perusahaan yang melakukan penawaran umum perdana di Bursa Efek Indonesia sebagai subjek penelitian dan penelitian ini akan menggunakan informasi-informasi non keuangan yang di proksi oleh informasi mengenai reputasi auditor, ownership retention, dan umur perusahaan sebagai objek penelitian.

Penelitian ini bertujuan mengetahui faktor-faktor yang mempengaruhi initial return dan return saham setelah 7 hari setelah penawaran umum perdana perusahaan-perusahaan yang go public di Bursa Efek Indonesia periode tahun 2011-2015. Dengan demikian perumusan masalah yang diajukan adalah sebagai berikut: 1) Apakah informasi non keuangan yang diproksi oleh reputasi auditor, ownership retention, dan umur perusahaan berpengaruh terhadap besarnya tingkat initial return pada perusahaan yang melakukan IPO?. 2) Apakah informasi non keuangan yang diproksi oleh reputasi auditor, ownership retention, dan umur perusahaan berpengaruh terhadap besarnya tingkat return saham 7 hari setelah perusahaan melakukan IPO?. 3) Apakah ada perbedaan pengaruh antara informasi non keuangan yang diproksi oleh reputasi auditor, ownership retention, dan umur perusahaan terhadap initial return dan return 7 saham hari setelah IPO?

\section{KAJIAN PUSTAKA}

Return Saham

Return merupakan hasil yang diperoleh dari investasi. Return dapat berupa return realisasi (realized return) yakni return yang telah terjadi yang dihitung berdasarkan data historis berfungsi sebagai salah satu pengukur kinerja perusahaan (Jogiyanto, 2003: 109). Return ekspektasi (expected return) yakni return yang diharapkan akan diperoleh oleh investor di masa mendatang. Setiap investasi baik jangka pendek maupun jangka panjang mempunyai tujuan utama untuk mendapatkan keuntungan yang disebut return baik langsung maupun tidak langsung. Penelitian bertujuan mengetahui apakah informasi non keuangan (reputasi auditor, ownership retention, dan umur perusahaan) mempengaruhi return saham yang dilihat dari initial return dan return 7 hari saham-saham perusahaan yang melakukan IPO.

Initial return (IR) adalah selisih antara harga IPO dan harga saat saham listing di bursa. Saham yang dipasarkan di Bursa Efek memiliki satuan nominal yang berbeda sementara aturan perubahan pergerakan perdagangan baru disesuaikan berikutnya. Nilai nominal saham saat IPO yang tinggi relatif menghasilkan nilai prosentase initial return yang kecil walaupun secara nominal memiliki nilai yang sama. Initial return dapat dihitung dengan melihat selisih antara harga saham pada hari pertama penutupan di pasar sekunder dengan harga saham pada penawaran perdana dibagi dengan harga saham penawaran perdana, sehingga dapat dirumuskan:

$\begin{array}{lll}\mathrm{IR} & =\frac{\mathrm{P}_{\mathrm{t} 1}-\mathrm{P}_{\mathrm{t} 0}}{\mathrm{P}_{\mathrm{t} 0}} \mathrm{x} \quad 100 \% \\ \text { Dimana: } & \\ \mathrm{IR}= & \text { Initial Return } \\ \text { Pt0 }= & \text { Harga saham penawaran perdana } \\ \text { Pt1 }= & \text { Harga saham penutupan pada hari pertama di pasar sekunder }\end{array}$

Return saham 7 hari setelah IPO dihitung dengan dengan melihat selisih antara harga saham pada hari ke tujuh penutupan di pasar sekunder dengan harga saham pada penawaran perdana dibagi dengan harga saham penawaran perdana, sehingga dapat dirumuskan:

$\mathrm{R}_{7}$ hari $=\frac{\mathrm{P}_{\mathrm{t} 7}-\mathrm{P}_{\mathrm{t} 0}}{\mathrm{P}_{\mathrm{t} 0}} \times \quad \mathrm{x} \quad 100 \%$

Dimana:

R7hari $=\quad$ Return saham setelah 7 hari IPO

Pt0 = Harga saham penawaran perdana 
Pt7 = Harga saham penutupan pada hari ke 7 di pasar sekunder

\section{Reputasi Auditor}

Reputasi auditor yang baik adalah auditor yang berafiliasi dengan Kantor Akuntan Publik (KAP) besar yang berlaku universal yang dikenal dengan Big Four Worldwide Accounting Firm (Ikhsan dkk., 2012: 5). Dalam dunia profesi akuntan publik dikenal KAP kelompok besar atau sering disebut dengan big four dan non big four. Maka KAP di Indonesia yang berafiliasi dengan big four juga disebut KAP big four (Deloitte, Pricewaterhouse Coopers, Ernst \& Young, dan KPMG), dan yang lain disebut kelompok KAP sedang dan kelompok KAP kecil. Sebenarnya pengelompokan ini bersifat informal dan lebih banyak diukur bukan dari jumlah penghasilannya tetapi dari jumlah auditornya. Pemeriksaan akuntansi atau audit adalah pemeriksaan yang berkaitan dengan kegiatan memperoleh dan mengevaluasi bukti tentang laporanlaporan entitas dengan maksud agar dapat memberikan pendapat apakah laporan-laporan tersebut telah disajikan secara wajar sesuai dengan kriteria yang telah ditetapkan, yaitu prinsip-prinsip akuntansi yang berlaku umum (Boynton et al., 2006: 6). Audit merupakan suatu proses untuk mengurangi ketidakselarasan informasi yang terdapat antara manajer dan para pemegang saham dengan menggunakan pihak luar untuk memberikan pengesahan terhadap laporan keuangan.

Auditor yang mempunyai reputasi tinggi, akan mempertahankan reputasinya dengan memberikan kualitas yang tinggi terhadap hasil auditannya (Kristiantari, 2012: 23). Jika kualitas pengauditannya tinggi, maka auditor akan dihargai dalam bentuk premium harga oleh klien (emiten). Penggunaan auditor yang profesional dijadikan sebagai tanda terhadap kualitas perusahaan emiten. Dengan memakai auditor profesional akan mengurangi kesempatan emiten untuk berlaku curang dalam menyajikan informasi yang tidak akurat ke pasar saham. Perusahaan akan memakai auditor yang berkualitas atau mempunyai reputasi tinggi agar investor tertarik untuk membeli sahamnya karena sudah terjamin atau merasa aman untuk berinvestasi ke perusahaan tersebut. Pengorbanan emiten untuk memakai auditor yang berkualitas akan diinterpretasikan oleh investor bahwa emiten mempunyai informasi yang tidak menyesatkan mengenai prospeknya pada masa mendatang. Hal ini berarti bahwa penggunaan auditor yang memiliki reputasi tinggi akan mengurangi ketidakpastian pada masa mendatang. Status reputasi auditor yang profesional dapat mempengaruhi tingkat discount dalam dua cara. Pertama auditor yang bereputasi baik akan mengurangi kesempatan emiten untuk berlaku curang dalam menyajikan informasi yang tidak akurat ke pasar. Pengorbanan investor ini di pasar dinterpretasikan investor sebagai penunjuk bahwa emiten mempunyai informasi yang tidak menyesatkan mengenai prospek emiten di masa mendatang. Kedua auditor, yang mempunyai reputasi baik pada umumnya mempunyai pengalaman yang lebih banyak sehingga dapat meramalkan harga pasar lebih akurat daripada auditor yang belum berpengalaman. Berarti auditor yang memiliki reputasi akan meningkatkan initial return dan return post IPO seperti periode 7 hari setelah IPO. Hal ini sesuai dengan penelitian Murdiyani (2009) yang menyatakan secara parsial dan simultan reputasi auditor berpengaruh terhadap initial return dan didukung pula oleh penelitian Widarjo et al (2010) yang menyatakan reputasi auditor berpengaruh terhadap initial return dan return saham 7 hari setelah IPO. Atas dasar hal ini, maka diajukan hipotesis:

$\mathrm{H} 1$ : Reputasi auditor berpengaruh terhadap initial return.

H2 : Reputasi auditor berpengaruh terhadap return saham 7 hari setelah IPO.

\section{Ownership Retention}

Menurut Widarjo et al. (2010) kepemilikan saham yang masih dipertahankan oleh pemilik lama adalah persentase penyertaan saham pemilik lama yang masih dipertahankan oleh pemilik lama setelah perusahaan melakukan penawaran umum perdana. Ownership retention didefinisikan sebagai proporsi jumlah saham yang masih ditahan oleh pemegang saham lama (pemilik perusahaan yang menghantarkan perusahaan go pubic). Jog dan McConomy dalam Firdaus (2011) menemukan bukti bahwa besarnya proporsi saham yang dipertahankan perusahaan (ownership retention) pada waktu IPO merupakan sinyal bagi pasar mengenai kualitas perusahaan.

Perusahaan dengan kualitas IPO yang baik dapat meningkatkan nilai perusahaan dan menarik perhatian para investor sehingga memberi keuntungan bagi perusahaan. Penelitian yang dilakukan oleh Hartono (2006) memperoleh hasil bahwa proporsi kepemilikan saham yang masih dipertahankan oleh 
pemilik lama (ownership retention) merupakan sinyal positif nilai perusahaan setelah penawaran umum perdana. Prediksi teori signal oleh Leland dan Pyle dalam Hartono, (2006) menyatakan bahwa di bawah kondisi normal pemilik lama secara monotonik meningkatkan retensi kepemilikannya. Widarjo et al. (2010) dalam penelitiannya menyatakan bahwa proporsi kepemilikan saham yang masih dipertahankan oleh pemilik lama berpengaruh positif terhadap initial return dan return post IPO . Sehingga diajukan hipotesis:

H3 : Reputasi auditor berpengaruh terhadap initial return.

H4 : Reputasi auditor berpengaruh terhadap return saham 7 hari setelah IPO.

\section{Umur perusahaan}

Umur perusahaan merupakan salah satu hal yang dipertimbangkan investor dalam menanamkan modalnya (Chishty, Muhammad, Hasan \& Smith, 1996). Umur perusahaan emiten menunjukkan seberapa lama perusahaan mampu bertahan dan menjadi bukti perusahaan mampu bersaing dan dapat mengambil kesempatan bisnis yang ada dalam perekonomian. Wahyudi (2004) menjelaskan bahwa umur perusahaan dihitung dengan mengurangi tahun penawaran saat IPO dengan tahun pada saat perusahaan berdiri. Perusahaan yang beroperasi lebih lama dianggap sudah matang dan bisa di persepsikan sudah tahan uji sehingga kadar risikonya rendah serta mempunyai kenaikan yang lebih besar untuk menyediakan informasi perusahaan yang lebih banyak dan luas daripada yang baru saja berdiri (Nurhidayati et.al., 1998). Dengan demikian akan mengurangi adanya informasi asimetri dan memperkecil ketidakpastian pasar yang pada akhirnya akan menurunkan tingkat underpricing saham dan peluang terciptanya initial return yang akan diterima investor kian rendah. Dengan demikian, pada umumnya semakin lama umur perusahaan maka peluang terciptanya initial return dan return 7 hari setelah IPO akan rendah. Hal ini didukung oleh penelitian Rahmanto dan Suherman (2014) menyatakan umur perusahaan mempengaruhi variabel initial return sebesar 5,2\% dan didukung penelitian Indah (2006) yang menyatakan umur perusahaan berpengaruh terhadap initial return dan return 7 hari setelah IPO. Hipotesis yang diajukan selanjutnya:

H5 : Umur perusahaan berpengaruh terhadap initial return.

H6 : Umur perusahaan berpengaruh terhadap return saham 7 hari setelah IPO.

\section{METODE PENELITIAN}

Sifat Penelitian

Sifat penelitian dalam penelitian ini adalah desain kausal dimana berguna untuk menganalisis hubunganhubungan antara satu variabel dengan variabel lainnya atau bagaimana suatu variabel mempengaruhi variabel lainnya. Sifat hubungan yang terjadi di antara variabel-variabel ini adalah hubungan asimetris yaitu terjadi jika variabel bebas mempengaruhi variabel terikatnya.

Sumber dan Jenis Data

Sumber data dalam penelitian ini berasal dari data sekunder dimana data yang dibutuhkan dalam penelitian ini adalah:1. Daftar perusahaan emiten yang melakukan penawaran umum perdana pada tahun 2011-2015 di Bursa Efek Indonesia.2. Daftar harga saham perdana, harga saham pada hari pertama dan harga saham 7 hari kerja setelah IPO di pasar sekunder.3. Data reputasi auditor, ownership retention, dan umur perusahaan. Jenis data sekunder yang dipakai dalam penelitian ini berdasar sumber pengambilannya berasal dari data eksternal dimana data-data tersebut diperoleh dari www.sahamok.com, www.sg.finance.yahoo.com, prospektus, Indonesian Capital Market Directory (ICMD), JSX Fact Book, dan http/ / www.jsx.co.id.

Populasi dan Sampel

Penelitian mengambil populasi dari perusahaan-perusahaan yang tercatat di Bursa Efek Indonesia. Yang dijadikan sampel adalah perusahaan-perusahaan yang melakukan penawaran umum perdana di Bursa Efek Indonesia dari tahun 2011 sampai dengan 2015. Metode pengambilan sampel dalam penelitian ini dilakukan dengan menggunakan metode purposive sampling, yaitu metode pemilihan sampel dengan 
kriteria tertentu. Kriteria sampel dalam penelitian ini adalah: (1). Sampel merupakan perusahaanperusahaan yang melakukan penawaran umum perdana di Bursa Efek Indonesia di tahun 2011, 2012, 2013, 2014, dan 2015. (2). Perusahaan harus sudah listing pada awal periode pengamatan dan tidak delisting sampai dengan akhir periode pengamatan. 3.Perusahaan yang mengalami underpriced pada saat hari pertama di pasar sekunder.

Variabel Penelitian dan Operasionalisasi Variabel

Variabel independen: (1) Reputasi auditor. Dalam penelitian ini reputasi auditor merupakan variable dummy yang diukur berdasarkan reputasi kantor akuntan publik yang mengaudit perusahaan. Dalam penelitian ini KAP yang berafiliasi dengan KAP big four diberi angka 1, dan 0 untuk KAP non big four. Pengukuran variable ini berdasarkan pada penelitian Wibowo (2010). (2) Ownership retention. Prosentase saham yang dipegang oleh pemilik menunjukkan banyak sedikitnya pengungkapan informasi private perusahaan. Informasi kepemilikan saham oleh pemilik akan digunakan oleh investor sebagai pertanda bahwa prospek perusahaannya baik. Semakin besar tingkat kepemilikan yang ditahan akan memperkecil ketidakpastian. 3) Umur perusahaan. Variabel ini diukur dengan lamanya perusahaan beroperasi sejak didirikan berdasarkan akte pendirian sampai dengan saat perusahaan tersebut melakukan IPO di bursa. Umur perusahaan dihitung dengan skala tahun.

Variabel dependen, Initial return. Merupakan selisih antara harga saham pada hari pertama penutupan di pasar sekunder dengan harga saham pada penawaran perdana dibagi dengan harga saham penawaran perdana. Diukur berdasarkan perhitungan initial return perusahaan-perusahaan yang melakukan initial public offering selama periode 2011-2015. 2) Return 7 hari setelah IPO. Variabel ini diukur dengan menggunakan mean adjusted model nilai return selama 7 hari setelah IPO.

\section{HASIL DAN PEMBAHASAN}

Analisis Hasil Regresi Initial Return

Setelah asumsi klasik terpenuhi, dilakukan analisis regresi linier berganda dengan hasil yang dijelaskan sebagai berikut:

Hipotesis penelitian ini di uji dengan melakukan regresi linear berganda antara variabel dependen dengan variabel independen. Signifikansi model regresi memberikan dasar untuk menerima atau menolak hipotesis penelitian. Kesimpulan mengenai hipotesis setiap variabel independen ditentukan dengan tanda positif atau negatif, dan signifikansinya dengan koefisien regresi variabel yang bersangkutan. Uji t digunakan untuk menguji tingkat signifikansi pengaruh masing-masing variabel independen terhadap variabel dependen. Sedangkan uji F digunakan untuk menguji pengaruh variabel independen terhadap variabel dependen secara bersama-sama. Berdasar hasil analisis regresi linier berganda. antara variabelvariabel reputasi auditor, ownership retention, dan umur perusahaan terhadap initial return, maka dapat disusun persamaan regresi:

Tabel 1. Hasil Regresi Pertama

\begin{tabular}{|c|c|c|c|}
\hline Variabel & Koefisien & Thitung & Sig \\
\hline Reputasi Auditor (Raud) & $-0,664$ & $-2,352$ & 0,021 \\
\hline Ownership retention(LnOwnR) & $-0,088$ & $-0,279$ & 0,781 \\
\hline Umur perusahaan (LnAge) & $-0,105$ & $-0,871$ & 0,386 \\
\hline F-statistik & 2,880 & & \\
\hline
\end{tabular}

LnIR $=-1,581$ - 0,664Raud - 0,088LnOwnR - 0,105 LnAge +e

Berdasar persamaan regresi diatas, maka dapat dilakukan uji hipotesa penelitian.

Uji Hipotesis Regresi model regresi 1

Pengujian hipotesis 1 pengaruh reputasi auditor terhadap initial return. Hasil pengujian parameter pengaruh RAud diperoleh nilai t-hitung sebesar $-2,352$. Nilai t-tabel dengan $\mathrm{df}=\mathrm{n}-\mathrm{k}-1=101-3-1=$ 97 diperoleh t-tabel sebesar 1,66071. Sehingga didapatkan nilai t-hitung absolut lebih besar daripada t- 
tabel $(2,352>1,66071)$. Selain itu tingkat signifikansi menunjukkan 0,021 yang lebih kecil dari taraf signifikansi 0,05. Dengan demikian dapat disimpulkan bahwa hipotesis 1 yang diajukan dalam penelitian ini yakni H1: Reputasi auditor berpengaruh terhadap initial return diterima. Hal ini menunjukkan bahwa auditor yang mempunyai reputasi tinggi, akan mempertahankan reputasinya dengan memberikan kualitas yang tinggi terhadap hasil auditannya sehingga menyajikan informasi yang akurat ke pasar saham. Penggunaan auditor yang profesional dijadikan sebagai tanda terhadap kualitas perusahaan emiten sehingga investor tertarik untuk membeli saham emiten karena sudah terjamin atau merasa aman untuk berinvestasi ke perusahaan tersebut.

Pengujian hipotesa 3 pengaruh ownership retention terhadap initial return. Hasil pengujian variabel ownership retention diperoleh nilai t-hitung sebesar $-0,279$. Nilai t-tabel dengan $\mathrm{df}=\mathrm{n}-\mathrm{k}-1=101-3-1$ $=97$ diperoleh $\mathrm{t}$-tabel sebesar 1,66071. Untuk pengujian hipotesis maka diperoleh $\mathrm{t}$-hitung $-0,279<\mathrm{t}$ tabel 1,66071 dengan tingkat signifikansi 0,781. Tingkat signifikansi variabel ownership retention yang berada diatas dari taraf signifikansi 0.05 bisa disimpulkan bahwa hipotesis 3 yakni H3: ownership retention berpengaruh terhadap initial return ditolak, yang artinya bahwa informasi proporsi kepemilikan saham yang masih dipertahankan oleh pemilik lama tidak akan meningkatkan jumlah permintaan dan penawaran saham ketika IPO sehingga tidak berakibat terhadap initial return saham. Hal ini menunjukkan bahwa informasi prosentase kepemilikan saham kurang diperhatikan investor dalam berinvestasi di pasar modal, karena belum tentu perusahaan yang memiliki kepemilikan tinggi akan memberikan nilai return yang tinggi.

Pengujian hipotesa 5 pengaruh variabel umur perusahaan terhadap initial return. Hasil pengujian variabel umur perusahaan memberikan nilai t-hitung sebesar $-0,871$. Nilai t-tabel dengan $\mathrm{f}=\mathrm{n}-\mathrm{k}-1=$ $101-3-1=97$ diperoleh t-tabel sebesar 1,66071. Untuk pengujian hipotesis maka diperoleh t-hitung $0,871<$ t-tabel 1,66071 dengan tingkat signifikansi 0,386. Tingkat signifikansi variabel umur perusahaan yang berada diatas taraf signifikansi 0,05 bisa disimpulkan bahwa hipotesis 5 yakni H5: umur perusahaan berpengaruh terhadap initial return ditolak, yang artinya bahwa informasi umur perusahaan ketika IPO tidak akan meningkatkan jumlah permintaan dan penawaran saham ketika IPO sehingga tidak berakibat terhadap initial return saham. Hal ini menunjukkan bahwa bagi para investor, umur perusahaan tidak dapat dijadikan patokan dalam melihat kualitas perusahaan, karena belum tentu perusahaan yang berumur lebih muda mempunyai kinerja atau prospek yang kurang baik dibanding dengan perusahaan yang telah lama berdiri.

Hasil hipotesa pengaruh reputasi auditor, ownership retention, dan umur perusahaan berpengaruh secara bersama-sama terhadap besarnya tingkat initial return, menunjukkan nilai $F$ sebesar 2,880 dengan signifikansi pengujian sebesar 0,008. Nilai signifikansi tersebut lebih kecil dari 0,05. Dengan demikian dapat disimpulkan bahwa variabel independen yakni reputasi auditor, ownership retention, dan umur perusahaan berpengaruh secara bersama-sama terhadap besarnya tingkat initial return. Nilai Koefisien Determinasi. Digunakan untuk mengetahui seberapa besar kontribusi/pengaruh variabel independen yakni variabel reputasi auditor, ownership retention, dan umur perusahaan terhadap variabel dependen yaitu initial return. Hasil R Square adalah 0,160 lebih kecil dari 0,5 berarti kemampuan variabel-variabel independen dalam menjelaskan variabel dependen sangat terbatas. Output adjusted $\mathrm{R}^{2}$ adalah 0,131 . Hal ini berarti 13,1\% variabel initial return dapat dijelaskan oleh variasi ke tiga variabel independen yakni reputasi auditor, ownership retention, dan umur perusahaan secara bersama-sama. Sedangkan sisanya yaitu 86,9\% dipengaruhi oleh variabel-variabel lain diluar model penelitian.

Analisis Hasil Regresi Return 7 Hari Setelah IPO

Tabel 2. Hasil Regresi

\begin{tabular}{lccc}
\hline Variabel & Koefisien & T hitung & Sig \\
\hline Reputasi Auditor (Raud) & $-0,384$ & $-1,116$ & 0,267 \\
Ownership retention(LnOwnR) & 0,129 & 0,338 & 0,736 \\
Umur perusahaan (LnAge) & $-0,353$ & $-2,402$ & 0,018 \\
\hline F-statistik & 2,841 & & \\
Adj. R Square & 0,141 & & \\
\hline
\end{tabular}


Berdasar hasil analisis regresi linier berganda antara variabel-variabel reputasi auditor, ownership retention, dan umur perusahaan terhadap return 7 hari setelah IPO, didapat persamaan regresi:

$\mathrm{R7Hr}=1,590-0,384 \mathrm{RAud}+0,129$ LnOwnR - 0,353LnAge +e

Berdasar persamaan regresi, maka dapat dilakukan uji hipotesa penelitian sebagai berikut:

Pengujian hipotesis 2 pengaruh Reputasi auditor terhadap return saham 7 hari setelah IPO. Hasil pengujian parameter pengaruh RAud diperoleh nilai t-hitung sebesar $-1,116$. Nilai $t$-tabel dengan $\mathrm{df}=\mathrm{n}-\mathrm{k}$ - 1 = $101-3-1$ = 97 diperoleh t-tabel sebesar 1,66071. Sehingga didapatkan nilai t-hitung lebih kecil daripada t-tabel $(-1,116<1,66071)$. Selain itu tingkat signifikansi menunjukkan 0,267 yang lebih besar dari taraf signifikansi 0,05. Dengan demikian dapat disimpulkan bahwa hipotesis 2 yang diajukan dalam penelitian ini yakni H2: Reputasi auditor berpengaruh terhadap return saham 7 hari setelah IPO ditolak. Hal ini menunjukkan bahwa setelah 7 hari saham diperdagangkan di pasar sekunder tidak dipengaruhi oleh reputasi auditor. Hal ini menunjukkan bahwa investor dalam mengambil keputusan investasinya untuk memperoleh return di pasar sekunder kurang memperhatikan informasi mengenai reputasi auditor yang terdapat dalam prospektus.

Pengujian hipotesa 4 pengaruh ownership retention terhadap return saham 7 hari setelah IPO. Hasil pengujian variabel ownership retention diperoleh nilai t-hitung sebesar 0,338 . Nilai t-tabel dengan $\mathrm{df}=\mathrm{n}$ $\mathrm{k}-1=101-3-1=97$ diperoleh $\mathrm{t}$-tabel sebesar 1,66071. Untuk pengujian hipotesis maka diperoleh $\mathrm{t}$ hitung $0,338<\mathrm{t}$-tabel 1,66071 dengan tingkat signifikansi 0,736. Tingkat signifikansi variabel ownership retention yang berada diatas dari taraf signifikansi 0,05 bisa disimpulkan bahwa hipotesis 4 yakni H4: ownership retention berpengaruh terhadap return saham 7 hari setelah IPO ditolak, yang artinya bahwa informasi proporsi kepemilikan saham yang masih dipertahankan oleh pemilik lama tidak akan meningkatkan jumlah permintaan dan penawaran saham ketika 7 hari setelah IPO sehingga tidak berakibat terhadap return saham. Hal ini menunjukkan bahwa investor dalam mengambil keputusan investasinya untuk memperoleh return di pasar sekunder kurang memperhatikan informasi mengenai ownership retention yang terdapat dalam prospektus.

Pengujian hipotesis 6 pengaruh variabel umur perusahaan terhadap return saham 7 hari setelah IPO. Hasil pengujian variabel umur perusahaan memberikan nilai t-hitung absolut sebesar 2,402. Nilai t-tabel dengan $\mathrm{f}=\mathrm{n}-\mathrm{k}-1=101-3-1=97$ diperoleh $\mathrm{t}$-tabel sebesar 1,66071. Untuk pengujian hipotesis maka diperoleh t-hitung 2,402 >t-tabel 1,66071 dengan tingkat signifikansi 0,018. Tingkat signifikansi variabel umur perusahaan yang berada dibawah taraf signifikansi 0,05 bisa disimpulkan bahwa hipotesis 6 yakni H6: Umur perusahaan berpengaruh terhadap return saham 7 hari setelah IPO diterima, yang artinya bahwa informasi umur perusahaan akan meningkatkan jumlah permintaan dan penawaran saham ketika 7 hari setelah IPO sehingga berakibat terhadap return saham.

Berdasar hasil Uji F. menunjukkan nilai F sebesar 2,841 dengan signifikansi pengujian sebesar 0,007. Nilai signifikansi tersebut lebih kecil dari 0,05. Dengan demikian dapat disimpulkan bahwa variabel independen yakni reputasi auditor, ownership retention, dan umur perusahaan berpengaruh secara bersama-sama terhadap besarnya tingkat return saham 7 hari setelah IPO. Dari hasil uji, output besarnya nilai koefisien determinasi ( $R$ Square) berada di antara nol dan satu. Jika nilai koefisien determinasi lebih kecil dari 0,5 berarti kemampuan variabel-variabel independen dalam menjelaskan variabel dependen sangat terbatas, sebaliknya jika nilai koefisien determinasi lebih besar dari 0,5 berarti variabel-variabel independen memberikan hampir semua informasi yang dibutuhkan untuk memprediksi variabel dependen. Hasil R Square adalah 0,169 lebih kecil dari 0,5 berarti kemampuan variabel-variabel independen dalam menjelaskan variabel dependen sangat terbatas. Output adjusted $\mathrm{R}^{2}$ adalah 0,141 . Hal ini berarti 14,1\% variabel return saham 7 hari setelah IPO dapat dijelaskan oleh variasi ke tiga variabel independen yakni reputasi auditor, ownership retention, dan umur perusahaan secara bersama-sama. Sedangkan sisanya yaitu 85,9\% dipengaruhi oleh variabel-variabel lain diluar model penelitian. 


\section{KESIMPULAN}

Berdasarkan pembahasan yang telah diuraikan maka ditarik simpulan sebagai berikut : pertama, Hasil analisis regresi terhadap initial return menunjukkan bahwa secara parsial hanya variabel reputasi auditor yang berpengaruh signifikan pada alpha 0,05 . Koefisien regresi menunjukkan arah negatif yang berarti semakin bagus reputasi auditor maka semakin kecil initial return yang diterima investor. Variabelvariabel lain yaitu ownership retention dan umur perusahaan tidak berpengaruh terhadap initial return. Hasil analisis regresi secara simultan menunjukkan bahwa seluruh variabel independen secara bersamasama berpengaruh terhadap initial return. Nilai koefisien determinasi regresi ini menunjukkan nilai sebesar 0,16 yang berarti seluruh variabel independen dalam penelitian ini hanya mampu mempengaruhi initial return sebesar 16\%, sedangkan sisanya dipengaruhi oleh faktor-faktor lain diluar model.

Hasil analisis regresi terhadap return 7 hari setelah IPO menunjukkan bahwa secara parsial variabel umur perusahaan berpengaruh signifikan terhadap return 7 hari setelah IPO pada alpha 0,05. Koefisien regresi menunjukkan arah negatif yang berarti semakin lama umur perusahaan maka semakin kecil return yang diterima investor dan semakin kecil ukuran perusahaan maka semakin besar return yang diterima investor di pasar sekunder sampai hari ke 7 setelah perusahaan IPO. Variabel-variabel lain yaitu reputasi auditor dan ownership retention tidak berpengaruh terhadap return 7 hari setelah IPO. Hasil analisis regresi secara simultan menunjukkan bahwa seluruh variabel independen secara bersamasama berpengaruh terhadap return 7 hari setelah IPO. Nilai koefisien determinasi regresi ini menunjukkan nilai sebesar 0,169 yang berarti seluruh variabel independen dalam penelitian ini hanya mempengaruhi return 7 hari setelah IPO sebesar 16,9\% sedangkan sisanya dipengaruhi oleh faktor-faktor lain diluar model.

Implikasi

Implikasi manajerial yang dapat diaplikasikan berdasar hasil penelitian ini yakni bagi emiten, manajemen perusahaan hendaknya memperhatikan informasi-informasi yang tercermin dalam prospektus karena akan mempengaruhi investor dalam keputusan investasinya di pasar modal. Semakin besar keterbukaan informasi yang diberikan akan dianggap sebagai sinyal bagi investor dalam kepastian menanamkan dananya di pasar modal ketika perusahaan melakukan IPO. Bagi investor hendaknya memperhatikan informasi yang terdapat dalam prospektus terutama mengenai informasi reputasi auditor dan umur perusahaan yang sesuai hasil penelitian ini berpengaruh terhadap return saham (inital return dan return 7 hari setelah IPO).

\section{Keterbatasan}

Keterbatasan penelitian ini, peneliti meneliti di periode 2011-2015 dimana dalam periode 2014 dan 2015 terjadi penurunan jumlah perusahaan yang melakukan IPO diduga karena ketidakstabilan kondisi politik di Indonesia (momentum pemilu) sehingga disarankan untuk penelitian selanjutnya peneliti menggunakan periode ketika kondisi politik dan ekonomi sudah stabil guna mendukung kajian teori dan penelitian-penelitian sebelumnya. Keterbatasan selanjutnya peneliti menganalisis return post IPO yakni 7 hari setelah IPO. Penelitian berikutnya dapat mencoba menganalisis apakah informasi non keuangan berpengaruh setelah 14 hari IPO, 1 bulan IPO, dan seterusnya.

\section{REFERENSI}

Ang, R. (1997). Buku Pintar Pasar Modal Indonesia: Mediasoft Indonesia.

Iskandar, A. Z (2003). Pasar Modal Teori dan Aplikasi. Edisi Pertama. Penerbit Yayasan Pancur Siwah. Jakarta.

Boynton, W. C., \& Johnson, R. N. (2006). Modern auditing: Assurance services and the integrity of financial reporting. Wiley.

Chishty, M. R., Hasan, I., \& Smith, S. D. (1996). A note on underwriter competition and initial public offerings. Journal of Business Finance \& Accounting, 23(5-6), 905-914.

Daljono. (2000). Analisis faktor-faktor yang mempengaruhi initial return saham yang listing di BEJ tahun 1990 - 1997. Simposium Nasional akuntansi III. IAI. Depok. Hal. 556-569 
Jurnal Manajemen Strategi dan Aplikasi Bisnis, 2(2), 107-116

Rahmanto, B.T \& Febriansyah. Model hubungan informasi non keuangan...

Elton, E. J., Gruber, M. J., \& Blake, C. R. (1995). Fundamental economic variables, expected returns, and bond fund performance. The Journal of Finance, 50(4), 1229-1256.

Gerianta, W. Y, (2008), Penyebab Underpricing pada Penawaran Saham Perdana di Bursa Efek Indonesia, Jurnal Akuntansi dan Bisnis Vol 3, No. 2.

Hariyani, Iswi, dan R. Serfianto D.P. (2010). Buku pintar hukum bisnis pasar modal: Strategi tepat investasi saham, obligasi, waran, right, opsi, reksadana, \& produk pasar modal syariah. Penerbit Visimedia, Jakarta.

Hartono. (2006). Analisis Retensi Kepemilikan Pada Penerbitan Saham Perdana Sebagai Sinyal Nilai Perusahaan. Jurnal Bisnis dan Manajemen, 6(2), 141-162.

Indah, S. (2006). Analisis Pengaruh Informasi Keuangan dan Non Keuangan Terhadap Initial Return dan Return 7 Hari Setelah IPO di Bursa Efek Jakarta. Doctoral dissertation, program Pascasarjana Universitas Diponegoro.

Ikhsan, A.E., M. Nur, Y. , \& Saidaturrahmi, (2012), Peringkat Obligasi dan Faktor yang Mempengaruhinya, Pekbis Jurnal, Vol.4, No.2.

Jogiyanto, H.M. (2003). Teori portofolio dan analisis investasi (edisi 3). Penerbit BPFE, Yogyakarta.

Kristiantari, I D. A. (2012). Analisis Faktor-Faktor yang Mempengaruhi Underpricing Saham pada Penawaran Saham Perdana di Bursa Efek Indonesia, Tesis Universitas Udayana, Denpasar.

Murdiyani. (2009). Pengaruh Informasi Prospektus Perusahaan Terhadap Initial Return Pada Penawaran Saham Perdana (Studi Pada Perusahaan LQ-45 2001-2008). Doctoral dissertation, program Pascasarjana Universitas Diponegoro.

Nurhidayati, S \& Indriantoro, N. (1998). Analisis faktor-faktor yang berpengaruh terhadap tingkat underpriced pada penawaran perdana di Bursa Efek Jakarta. Jurnal Ekonomi dan Bisnis Indonesia. Vol. 13. No. 1.

Rahmanto, B.T. \& Suherman. (2014). Pengaruh Return On Assets, Earnings Per Share, Ukuran Perusahaan, Umur Perusahaan, dan Prosentase Penawaran Saham Terhadap Initial Return Penawaran Umum Perdana, Kalbisocio, Volume 1, Nomor 1, Hal. 54-65

Sembel, Roy H.M., (1996), IPO anomalies, truncated excess supply, and heterogeneous information. Unpublished Dissertation.J M Katz Graduate School of Business, University of Pittsburg, Pensylvania.

Wahyudi, S. (2004). Pengaruh umur perusahaan dan ukuran perusahaan sebagai assurance terhadap return awal saham. Jurnal Bisnis dan Akuntansi. Vol.6. No.2. Agustus.

Widarjo, W., Bandi., S. Hartoko. (2010). Pengaruh Ownership Retention, Investasi Dari Proceeds, dan Reputasi Auditor Terhadap Nilai Perusahaan Dengan Kepemilikan Manajerial dan Institusional Sebagai Variabel Pemoderasi. Kumpulan Makalah Simposium Nasional Akuntansi XIII, Purwokerto.

\section{PROFIL PENULIS}

Basuki Toto Rahmanto dan Febriansyah merupakan staf pengajar pada Prodi S1 Manajemen, Fakultas Bisnis, Institut Teknologi Dan Bisnis Kalbis yang beralamat di Jl. Pulomas Selatan Kav. 22, Jakarta Timur, 13210. 